\title{
CD8- Natural Killer Cells Are Greatly Enriched in the Human Gastrointestinal Tract and Have the Capacity to Respond to Bacteria
}

\author{
Åsa Lindgren ${ }^{a, b} \quad$ Cheol H. Yun ${ }^{a-d}$ Anna Lundgren ${ }^{a, b}$ Åsa Sjöling ${ }^{a, b}$ \\ Lena Öhman ${ }^{a, b}$ Ann-Mari Svennerholm ${ }^{a, b}$ Jan Holmgren ${ }^{a, b}$ \\ Samuel B. Lundin ${ }^{a, b}$ \\ a Department of Microbiology and Immunology, Institute of Biomedicine, and bucosal Immunobiology and \\ Vaccine Center (MIVAC), University of Gothenburg, Gothenburg, Sweden; ' International Vaccine Institute, \\ and ${ }^{\mathrm{d} D e p a r t m e n t}$ of Agricultural Biotechnology and Research Institute for Agriculture and Life Sciences, \\ Seoul National University, Seoul, Korea
}

\section{Key Words}

Human natural killer cells $\cdot$ Bacterial infection $\cdot$ Mucosal immunity $\cdot$ Cell surface molecules

\section{Abstract \\ Natural killer (NK) cells can be activated to produce IFN- $\gamma$ by lysate from Helicobacter pylori in combination with IL-12. Fur- thermore, NK cells in the gastrointestinal mucosa are likely to encounter $H$. pylori as well as other bacteria and may play a role in the mucosal innate immune defense. In this report, we show that in marked contrast to peripheral blood, the large majority of NK cells of human gastrointestinal mucosa lack CD8 expression. Importantly, we show that CD8 ${ }^{-}$and $\mathrm{CD}^{+} \mathrm{NK}$ cells have different functional properties; although the cytotoxic capacity of the different NK cell populations was equal, only CD8 ${ }^{-} \mathrm{NK}$ cells were capable of responding by IFN- $\gamma$ production to stimulation with lysates from $\mathrm{H}$. pylori and other bacteria - this was not due to an intrinsic defect in IFN- $\gamma$ production by $\mathrm{CD}^{+}$NK cells. We propose that $\mathrm{CD} 8^{-}$ CD16- CD56 $6^{\text {bright }} \mathrm{NK}$ cells constitute a subset of NK cells that}

is present in the gastrointestinal mucosa and is especially adapted to responding to bacterial infection by production of cytokines. These findings may have important implications for the understanding of NK cell subsets and the innate defense against gastrointestinal bacterial infections.

Copyright $\odot 2010$ S. Karger AG, Basel

\section{Introduction}

Natural killer (NK) cells have the ability to mediate innate immunity against pathogens and tumors. They make up 5-15\% of the blood lymphocytes and are also found in tissues such as the liver, peritoneal cavity and gastrointestinal mucosa [1]. They contribute to the protection against infections and cancers through two distinctive pathways: (i) the recognition and lysis of abnormal target cells and (ii) the production of cytokines and

\section{Å.L. and C.H.Y. contributed equally to the present work.}

\section{KARGER}

Fax +4161306 1234

E-Mail karger@karger.ch

www.karger.com (c) 2010 S. Karger AG, Basel

$1662-811 X / 10 / 0023-0294 \$ 26.00 / 0$

Accessible online at:

www.karger.com/jin
Åsa Lindgren

Department of Microbiology and Immunology

Institute of Biomedicine, and Mucosal Immunobiology and Vaccine Center (MIVAC)

University of Gothenburg, Box 435, SE-40530 Gothenburg (Sweden)

Tel. +4631786 6233, Fax +46 31786 6205, E-Mail asa.lindgren@microbio.gu.se 
chemokines to modulate the activity of other effector cells of the adaptive and innate immune systems $[2,3]$. Human NK cells are characterized by expression of the adhesion molecule CD56 but lack of the T-cell-receptorassociated molecule CD3. Furthermore, NK cells can be subdivided into several populations based on differential expression of CD56 and the Fc $\gamma$-receptor CD16 [4]. It has been suggested that at the resting stage the main cytotoxic activity resides in the $\mathrm{CD} 56^{\mathrm{dim}} \mathrm{CD} 16^{+}$population, while cytokine production is carried out by CD56 ${ }^{\text {bright }} \mathrm{CD} 16^{-} \mathrm{NK}$ cells [5-7]. The recognition of virally infected cells by NK cells is well documented. Furthermore, since NK cells are activated by cytokines such as IL-12 produced by other immune cells during acute infections, NK cells may also respond indirectly to infectious agents, including fungi and bacteria. Recently evidence has accumulated that NK cells can also be activated by bacterial products directly [8-9]. Thus, several different types of bacteria have been reported to activate human NK cells, including Salmonella typhi and Listeria monocytogenes [8].

In our studies of the role of NK cells in the immune response to the pathogenic bacterium Helicobacter $p y$ lori, we have demonstrated that $H$. pylori antigens may directly activate NK cells to secrete IFN- $\gamma$ [9]. This has also been reported previously using less pure NK cell preparations [10]. We also showed that IFN- $\gamma$ production by NK cells is not specific to $H$. pylori, since components from Escherichia coli bacteria also activated NK cells [9]. Furthermore, a synergistic effect was observed when bacterial lysate was added together with low levels of IL-12, which is produced by dendritic cells, monocytes and macrophages in the stomach mucosa infected by $H$. pylori [11]. Recently we have further shown that the activation of NK cells by $H$. pylori mirrors that of bacterial lipoproteins, indicating an involvement of TLR2 in the recognition of $H$. pylori by human NK cells [Lindgren et. al., in press]. Since NK cells are present in both the gastric and duodenal mucosa, we have proposed that NK cells, by their ability to secrete IFN- $\gamma$, are important components of the mucosal immune response to $H$. pylori infection [9]. The studies attempting to reveal the function of NK cells in humans have mainly been performed on cells obtained from peripheral blood. This may sometimes be misleading, since there are reports showing that the characteristics of NK cells in tissues are not identical to those of peripheral blood NK cells. For instance, it has been reported that NK cells in duodenal, colonic and decidual mucosa are predominantly $\mathrm{CD}_{16}{ }^{-}$, while more than $90 \%$ of the NK cells in peripheral blood are $\mathrm{CD} 16^{+}[12,13]$. Therefore, in order to make any conclusion/hypothesis about the function of mucosal NK cells in the defense against gastrointestinal infections, the NK cell populations present in $\mathrm{mu}-$ cosa have to be studied in greater detail. It is well established that human blood NK cells are divided into two populations based on presence or absence of CD8 expression [14-16]. Information about functional differences between these populations has been lacking until recently, when it was shown that ligation of CD8 on NK cells can inhibit apoptosis and instead enhance the cytolytic activity during the killing of target cells [17]. However, no research into the tissue localization of the two NK cell subsets has been performed. In this study we therefore investigated the properties of the gastrointestinal NK cells, with special emphasis on subsets distinguished by the presence or absence of the CD8 molecule. Furthermore, we also analyzed the reactivity to bacterial components by these different NK cell populations in order to assess any functional differences between the two NK cell subsets.

\section{Materials and Methods}

\section{Bacterial Preparation}

Lysates of H. pylori (strain Hel305, cagA $\mathrm{A}^{+}$and $\mathrm{vacA}^{+}$), enterotoxigenic E. coli (ETEC strain E11881/9, $\mathrm{ST}^{+}$and $\mathrm{LT}^{+}$) and Streptococcus mitis were prepared as previously described [18].

\section{Human Volunteers and Collection of Samples}

For the analysis of NK cells in the gastrointestinal mucosa, six $H$. pylori-infected and five uninfected adult volunteers (age $=24-$ 40 years) were recruited for the study. None of the volunteers had a history of gastrointestinal illnesses. The study was approved by the Ethics Review Board in Gothenburg, and informed consent was obtained from each volunteer before participation. Presence of $H$. pylori infection was identified by analysis of elevated serum IgG and IgA antibody titers against $H$. pylori by using ELISA as previously described [19], followed by subsequent confirmation by $H$. pylori culture from gastric biopsies. Gastroduodenal endoscopies or colonoscopies were performed and biopsies taken according to standard clinical procedures. Lamina propria cells were extracted from the biopsies using sequential EDTA, DTT and collagenase treatment, and mononuclear cells were isolated from blood and lamina propria samples, as previously described [20]. Peripheral blood NK cells were also purified from buffy coats enriched in leukocytes, obtained from healthy blood donors. Mononuclear cells (PBMC) were separated from the buffy coats using Ficoll-Paque gradient centrifugation, followed by NK cell purification as described below.

\section{Flow Cytometry}

For CD8 analysis, cells were stained with anti-CD3-FITC, anti-CD56-PE (both BD Bioscience) and anti-CD8-APC (Diatech 
or Miltenyi Biotech, Germany). Alternatively, cells were stained with anti-CD3-FITC, anti-CD56-PE-Cy5 (BD Bioscience), antiCD8-APC in combination with anti-granzyme A-PE or antiperforin-PE (BD Bioscience). Other cells were stained with antiCD16-PE, anti-CD56-AF488 (both BD Bioscience), anti-CD3PerCP and anti-CD8-APC. The cells were analyzed with FACSCalibur (BD Bioscience) using FlowJo software (Treestar, Ashland, Oreg., USA).

\section{Purification of NK Cells}

NK cells were isolated by negative selection using a magnetic bead isolation kit (Miltenyi Biotech). These semipurified NK cells were then further sorted using flow cytometry (FACSVantage SE, $\mathrm{BD}$ Bioscience). The sorted $\mathrm{CD}^{-} \mathrm{CD} 56^{+} \mathrm{CD} 8^{+}$and $\mathrm{CD}^{-}$ $\mathrm{CD} 56^{+} \mathrm{CD} 8^{-} \mathrm{NK}$ cell populations were $>99 \%$ pure. In parallel experiments, $\mathrm{CD}^{+}$and $\mathrm{CD}^{-}{ }^{-} \mathrm{NK}$ cells were also purified using magnetic beads (Miltenyi Biotech), to a purity of $>95 \%$.

\section{NK Cell Stimulation}

Fifty thousand viable NK cells were cultured for $48 \mathrm{~h}$ in the absence or presence of bacterial lysate and/or IL-12 in X-Vivo 15 medium (Lonza, Belgium) in round-bottom 96-well plates. The contents of IFN- $\gamma$ in supernatants were determined using an ELISA assay [21]. The survival of NK cells at $48 \mathrm{~h}$ of culture was analyzed by flow cytometry after staining with propidium iodide.

\section{Analysis of NK Cell Killing Activity}

Ten thousand NK-cell-sensitive target cells (K562) were cultured in the presence or absence of increasing numbers of $\mathrm{CD}^{-}$or $\mathrm{CD}^{+} \mathrm{NK}$ cells. After $2 \mathrm{~h}$ of culture the cells were harvested and stained with anti-CD71-APC and propidium iodide, and analyzed by flow cytometry. Target cells were identified by scatter profile combined with analysis of CD71; killed target cells lost CD71 staining but stained positive by propidium iodide.

Statistical Analysis

The data were analyzed by paired or unpaired t test, as appropriate, using GraphPad Prism (GraphPad Software).

\section{Results}

\section{Selective Presence of $\mathrm{CD}^{-} \mathrm{NK}$ Cells in the}

\section{Gastrointestinal Mucosa}

In previous research we have demonstrated that peripheral blood NK cells can be activated to produce IFN$\gamma$ by $H$. pylori lysate in combination with IL-12. In order to investigate NK cell responses to bacteria in greater detail, we aimed to study the characteristics of NK cells in the gastrointestinal mucosa, which are more likely to encounter bacteria and/or bacterial components in vivo. Therefore, we initially analyzed the CD8 expression of the NK cells present in the lamina propria of the stomach, duodenum and colon. The analysis revealed that while peripheral blood contained both $\mathrm{CD} 8^{+}$and $\mathrm{CD} 8^{-} \mathrm{NK}$ cells (mean frequencies $=31$ and $69 \%$, respectively), there was an almost exclusive presence of $\mathrm{CD} 8^{-} \mathrm{NK}$ cells in the gastrointestinal lamina propria (mean frequency $=96 \%$ in antral, 93\% in duodenal and $97 \%$ in colonic mucosa, fig. 1a-d). We also analyzed the presence of $\mathrm{CD}^{+}$and CD8 ${ }^{-}$NK cell subsets in the duodenal epithelium and found that the frequency of $\mathrm{CD} 8^{+} \mathrm{NK}$ cells was equally low in this compartment as in the subepithelial lamina propria mucosa ( $97 \% \mathrm{CD} 8^{-} \mathrm{NK}$ cells). These results were not due to a loss of CD8 molecules on the surface of NK cells during the enzymatic processing of the mucosal biopsies, since similar treatment of blood NK cells did not alter the percentages of $\mathrm{CD}^{+}$and $\mathrm{CD}^{-}$populations (data not shown). When individuals infected with $H$. $p y$ lori were compared to uninfected subjects, there was no difference in frequency of $\mathrm{CD} 8^{-} \mathrm{NK}$ cells in the stomach mucosa between the subject groups (data not shown). This result was expected, as we had previously demonstrated that $H$. pylori infection does not lead to an altered influx of NK cells in the gastric mucosa [9]. Thus, neither the distribution nor the total numbers of $\mathrm{CD} 8^{+}$and $\mathrm{CD} 8^{-}$ NK cells were altered during the course of infection. Analysis of CD56 expression by blood NK cells revealed that both $\mathrm{CD}^{+}$and $\mathrm{CD} 8^{-} \mathrm{NK}$ cells contain a CD56 ${ }^{\text {bright }}$ population, but there was a two-fold higher frequency of CD56 ${ }^{\text {bright }}$ cells among $\mathrm{CD}^{-}$compared to $\mathrm{CD} 8^{+} \mathrm{NK}$ cells (3 vs. 1.4\% median values, respectively, fig.1e). In the gastrointestinal mucosa there was an even higher frequency of $\mathrm{CD} 56^{\text {bright }}$ cells within the $\mathrm{CD} 8^{-} \mathrm{NK}$ cell population (fig. 1b, c). Examination of the CD16 expression within the $\mathrm{CD}^{+}$and $\mathrm{CD}^{-} \mathrm{NK}$ cell populations in the blood further showed that there were CD16-expressing cells in both populations. Thus, almost all $\mathrm{CD}^{+} \mathrm{NK}$ cells were $\mathrm{CD}^{+} 6^{+}$(median value $\left.=98.1 \%\right)$ in contrast to the CD8 ${ }^{-}$ NK cells, where both $\mathrm{CD}^{+} 6^{+}$(median value $\left.=87.1 \%\right)$ and $\mathrm{CD}^{-}{ }^{-}$(median value $\left.=12.9 \%\right)$ cells were detected (fig. 1f). Taken together, a relatively high frequency of $\mathrm{CD} 8^{-} \mathrm{NK}$ cells in the blood are CD56 ${ }^{\text {bright }}$ and $\mathrm{CD}^{-} 6^{-}$and hence may be skewed towards an immunoregulatory phenotype. Furthermore, the results show that the NK cells in the gastrointestinal mucosa are almost exclusively CD8 ${ }^{-}$ and to a large extent CD56 $6^{\text {bright }}$.

\section{Preferential Activation of $\mathrm{CD} 8^{-} \mathrm{NK}$ Cells by Bacterial Components}

NK cells from peripheral blood have previously been shown to respond to $H$. pylori lysate and IL-12 stimulation with IFN- $\gamma$ production [9]. To determine if mucosally derived NK cells possess the same ability as peripheral blood NK cells to respond to bacterial components, purified NK cells from healthy stomach mucosa were 
Fig. 1. Tissue distribution of $\mathrm{CD}^{-} \mathrm{NK}$ cells. a-d Cells from blood (a, d; $\mathrm{n}=11)$, antrum (b, d; $\mathrm{n}=11)$, duodenum $(\mathbf{c}, \mathbf{d} ; \mathrm{n}=$ 11) or colon $(\mathbf{d} ; n=3)$ were analyzed for CD3, CD8 and CD56 expression by flow cytometry. The contour plots show gated $\mathrm{CD}^{-} \mathrm{CD}^{-} 6^{+} \mathrm{NK}$ cells from one representative individual out of 11 . All results are expressed as means + SD. Statistical analysis was performed using the paired $t$ test; $p$ values: vs. blood samples. e Gated $\mathrm{CD} 8^{+}$ and $\mathrm{CD} 8^{-} \mathrm{NK}$ cells from peripheral blood were analyzed for CD56 ${ }^{\text {bright }}$ expression $(n=24)$ by flow cytometry. The results are expressed as geometric means with 95\% CI. Statistical analysis was performed using the Wilcoxon matched-pairs test; $p$ values: $\mathrm{CD}^{+}$vs. $\mathrm{CD}^{-} \mathrm{NK}$ cell populations. $f$ Gated $\mathrm{CD}^{+}$and $\mathrm{CD} 8^{-} \mathrm{NK}$ cells from peripheral blood were analyzed for CD16 expression $(n=3)$ by flow cytometry. The results are expressed as means + SD.
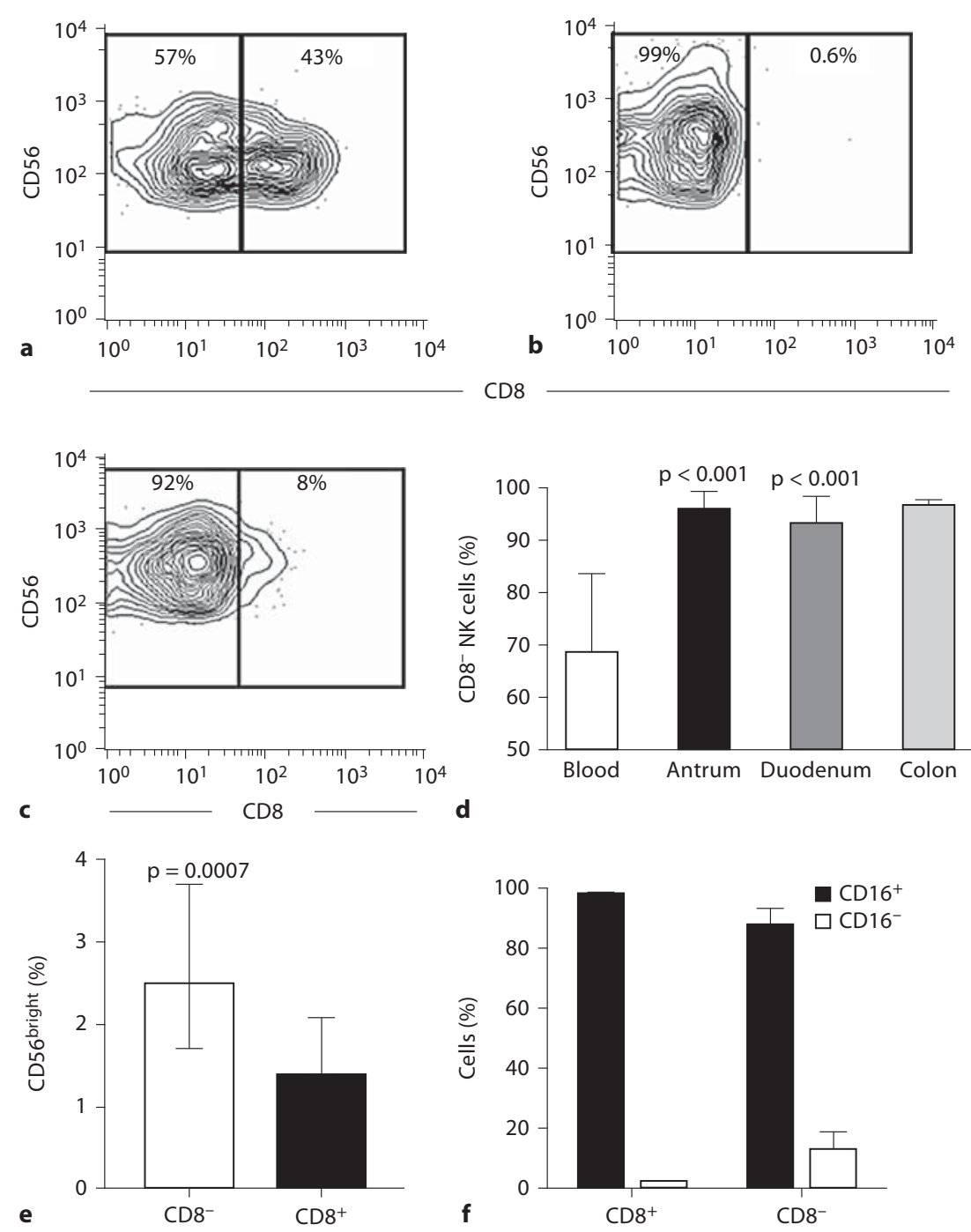

stimulated with $H$. pylori lysate in combination with IL12. The results show that mucosal NK cells did indeed respond with IFN- $\gamma$ production, however, in slightly lower levels compared to peripheral blood NK cells (fig. 2a). We decided to use blood NK cells as a model for the mucosal NK cells due to lack of sufficient mucosal material to evaluate the ability of $\mathrm{CD} 8^{-}$and $\mathrm{CD} 8^{+} \mathrm{NK}$ cell populations to respond to stimulation with bacterial lysate. $\mathrm{CD}^{+}$and $\mathrm{CD}^{-} \mathrm{NK}$ cells derived from PBMCs from healthy blood donors were therefore sorted to very high purity (99-100\%) and then stimulated with a combination of bacterial lysate and IL-12. There was indeed a large difference between NK cell subtypes in the ability to re- spond to bacterial stimulation: $\mathrm{CD} 8^{-} \mathrm{NK}$ cells produced around 10-fold higher levels of IFN- $\gamma$ after stimulation with IL-12 plus $H$. pylori lysate compared to $\mathrm{CD}^{+} \mathrm{NK}$ cells (fig. 2b). Confirming our previous findings [10], there was no IFN- $\gamma$ production observed after stimulation with $H$. pylori lysate alone (fig. $2 \mathrm{~b}$ ) or IL-12 alone (data not shown) with the concentrations used. Increasing the amount of $\mathrm{CD} 8^{+} \mathrm{NK}$ cells as high as three-fold did not lead to upregulation of IFN- $\gamma$ levels similar to those produced by the $\mathrm{CD}^{-}$cells, clearly demonstrating the increased potential of IFN- $\gamma$ production among $\mathrm{CD} 8^{-}$ NK cells after bacterial stimulation (fig. 2b). Similar results were also obtained when NK cell subsets were iso- 

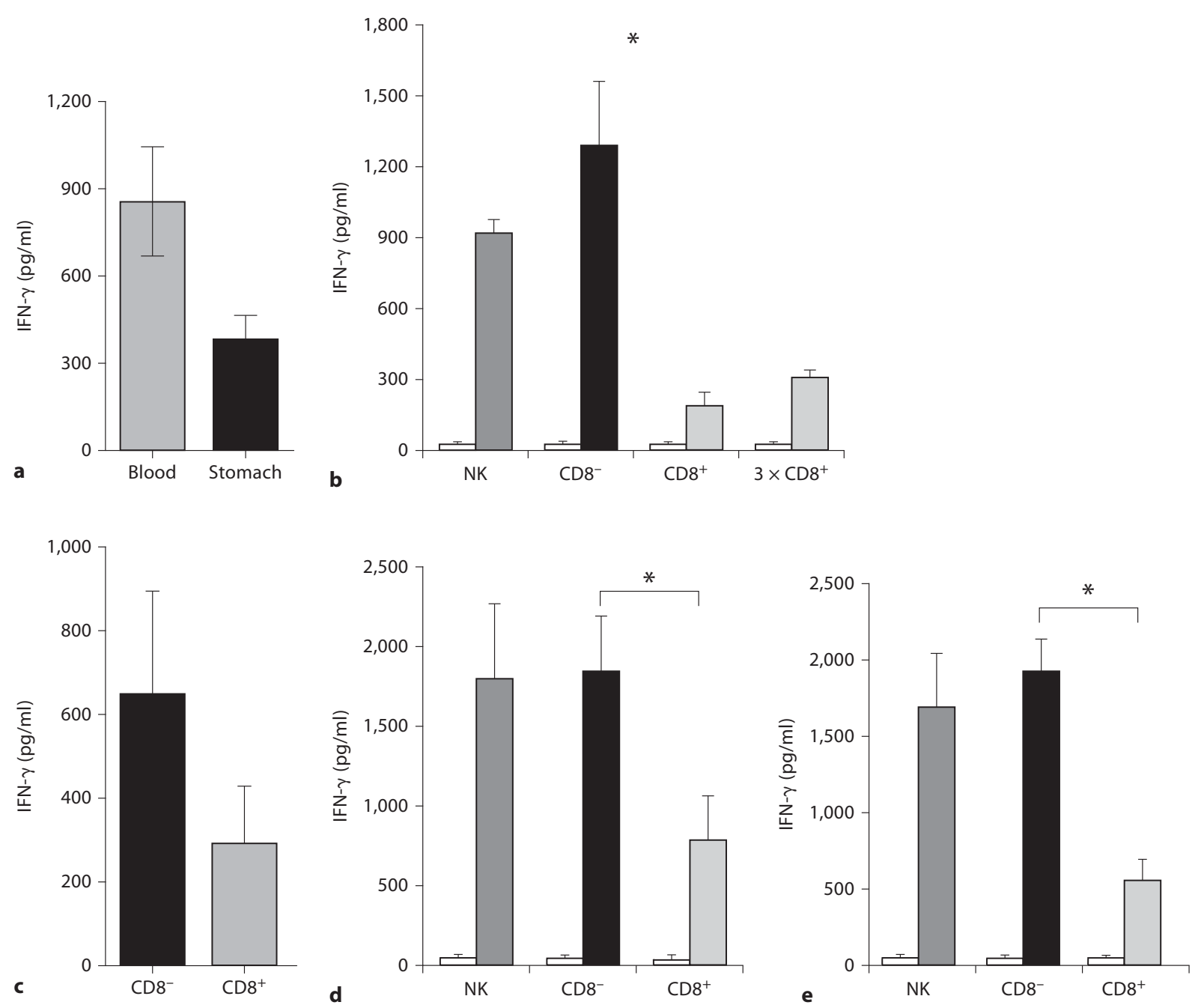

Fig. 2. $\mathrm{CD}^{-} \mathrm{NK}$ cells produce IFN- $\gamma$ in response to bacterial stimulation. a Flow-cytometry-sorted NK cells from stomach mucosa and peripheral blood were stimulated with $2 \mu \mathrm{g} / \mathrm{ml} H$. pylori lysate and $50 \mathrm{pg} / \mathrm{ml}$ IL-12 for $72 \mathrm{~h}$. The IFN- $\gamma$ content in supernatants was analyzed by ELISA. b-e NK cell subpopulations were sorted using flow cytometry (b, $\mathbf{d}$ and $\mathbf{e})$ or magnetic beads (c), and $\mathrm{CD}^{+}, \mathrm{CD}^{-}$or total NK cells were stimulated with $2 \mu \mathrm{g} /$ $\mathrm{ml}$ of $H$. pylori lysate (b and c), $2 \mu \mathrm{g} / \mathrm{ml}$ of ETEC lysate (d), $20 \mu \mathrm{g} /$

lated using magnetic beads, but since there were always some residual $\mathrm{CD}^{-}{ }^{-} \mathrm{NK}$ cells in the bead-isolated $\mathrm{CD} 8^{+}$ population, the differences in IFN- $\gamma$ production were not as pronounced (fig. 2c). $\mathrm{CD} 8^{-} \mathrm{NK}$ cells also produced large amounts of IFN- $\gamma$ in response to optimal concen- $\mathrm{ml}$ of Streptococcus mitis lysate (e) without (left bars) or with (right bars) $50 \mathrm{pg} / \mathrm{ml}$ of IL-12 for $48 \mathrm{~h}$. Cells stimulated with 50 $\mathrm{pg} / \mathrm{ml}$ of IL-12 alone did not produce detectable IFN- $\gamma$ levels. The IFN- $\gamma$ content in supernatants was analyzed by ELISA. The results are expressed as mean levels from at least four different individuals + SD. Statistical analysis was performed using the paired $\mathrm{t}$ test; ${ }^{*} \mathrm{p}<0.01$. The experiment in $\mathbf{b}$ was performed twice with similar results.

trations of lysate of other bacteria, both gram-negative and -positive (fig. $2 \mathrm{~d}$ and e, respectively).

Thus, these results clearly demonstrate a preferential activation of $\mathrm{CD} 8^{-} \mathrm{NK}$ cells after stimulation with bacterial components. 
Fig. 3. $\mathrm{CD}^{+} \mathrm{NK}$ cells induce IFN- $\gamma$ from nonbacterial stimulation. a-c NK cells or NK cell subsets were cultured in the presence of $50 \mathrm{ng} / \mathrm{ml}$ of PMA and $10 \mu \mathrm{M}$ of ionomycin for $24 \mathrm{~h}$ (a; $\mathrm{n}=4$ individuals) or 10 $\mathrm{ng} / \mathrm{ml}$ of IL-18 and $100 \mathrm{U} / \mathrm{ml}$ of IFN- $\alpha$ for $48 \mathrm{~h}$ (b; $\mathrm{n}=4$ individuals), or IL-18 and IFN- $\alpha$ at different concentrations $(\mathbf{c} ; n=2$ individuals) followed by analysis of IFN- $\gamma$ secretion by ELISA. The results are expressed as means + SD. d NK cell subsets were cultured in the presence or absence of $H$. pylori lysate and IL-12 for $48 \mathrm{~h}$, and the cell survival was measured by propidium iodide staining and flow cytometry $(\mathrm{n}=4$ individuals).

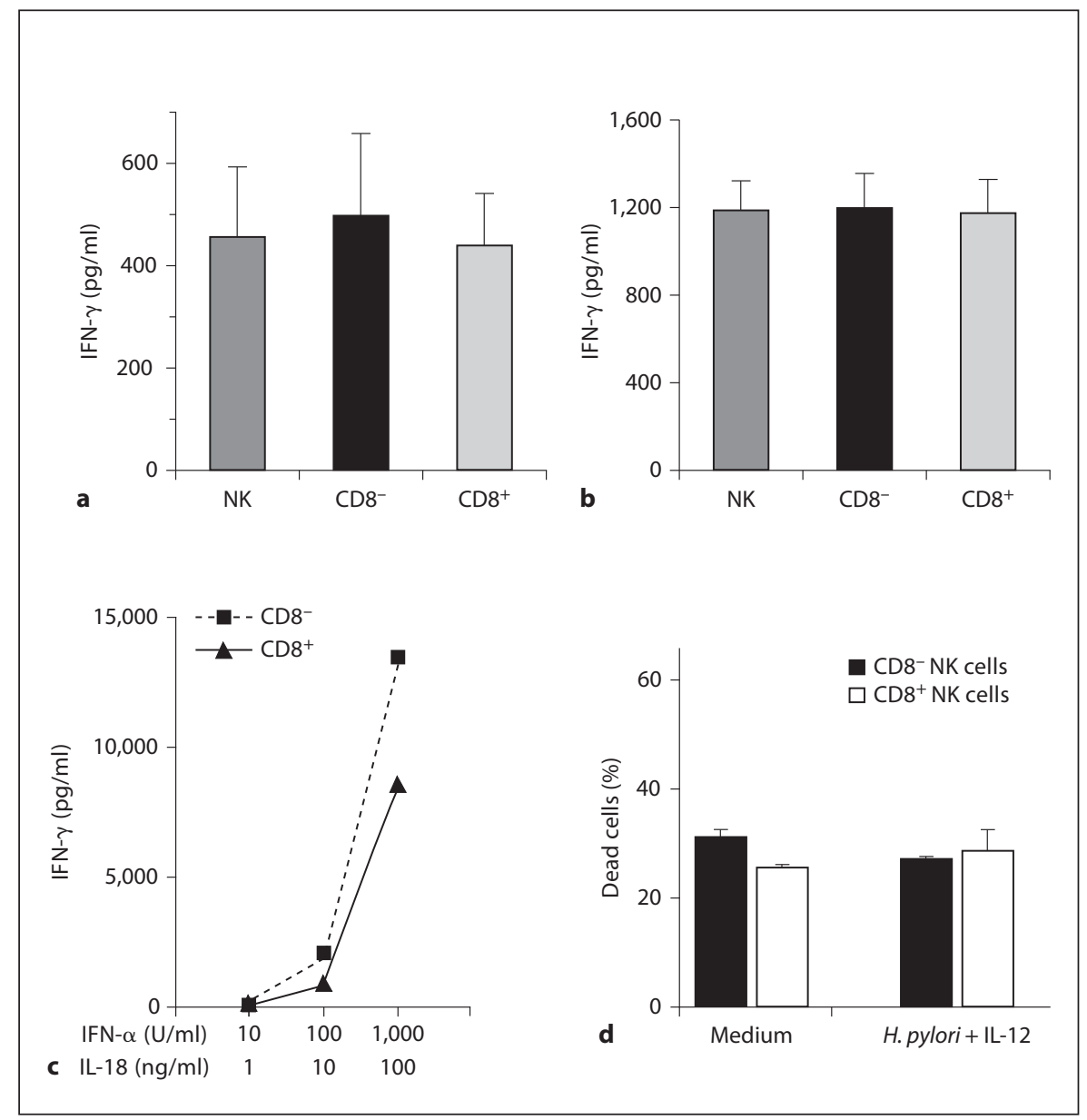

\section{$\mathrm{CD} 8^{+}$and $\mathrm{CD} 8^{-} \mathrm{NK}$ Cells Respond Similarly to Cytokine Stimulation}

The differential ability to respond to bacterial lysate was not due to an intrinsic defect in IFN- $\gamma$ production by the $\mathrm{CD} 8^{+} \mathrm{NK}$-cells, as there was no difference in IFN- $\gamma$ production between the populations after stimulation with combinations of PMA and ionomycin, or IL-18 and IFN- $\alpha$ (fig. 3a-c). This in combination with the results from the stimulations of magnetic bead-isolated NK cells (fig. 2c) ruled out the possibility that $\mathrm{CD} 8^{+} \mathrm{NK}$ cell functions were negatively affected by the sorting procedure. Thereafter, we investigated whether there was differential cell death by the two NK cell populations, after in vitro culture. We found that the increased levels of IFN- $\gamma$ were not due to differential survival in vitro of the two NK cell populations, since around $70 \%$ of both the unstimulated and stimulated $\mathrm{CD}^{+}$as well as $\mathrm{CD} 8^{-} \mathrm{NK}$ cells were alive at the end of culture (fig. $3 \mathrm{~d}$ ).
These results show that in contrast to after bacterial stimulation, $\mathrm{CD}^{+} \mathrm{NK}$ cells stimulated with cytokines alone do have the capacity to respond with IFN- $\gamma$ production.

\section{Similar Cytotoxic Capacity of $\mathrm{CD} 8^{+}$and $\mathrm{CD} 8^{-} \mathrm{NK}$ Cells}

A similar cytotoxic capacity of $\mathrm{CD}^{+}$and $\mathrm{CD}^{-} \mathrm{NK}$ cells was suggested by flow cytometric analysis of cytotoxicity-related molecules. The majority of both $\mathrm{CD} 8^{+}$ and $\mathrm{CD}^{-} \mathrm{NK}$ cells expressed granzyme A and perforin, which are important effectors of NK cell cytotoxicity (fig. 4a). This was supported by experiments where the natural killer activity of sorted $\mathrm{CD} 8^{+}$and $\mathrm{CD} 8^{-} \mathrm{NK}$ cells was analyzed by using the NK-sensitive cell line K562. In these experiments $\mathrm{CD}^{-}$and $\mathrm{CD}^{+}{ }^{+} \mathrm{NK}$ cells were equally effective in killing K562 cells (fig. 4b). Hence, the cytotoxic capacity did not differ between the two populations. 
Fig. 4. Similar survival and cytokine production capacity by $\mathrm{CD}^{+}$and $\mathrm{CD} 8^{-} \mathrm{NK}$ cells. a $\mathrm{CD} 8^{+}$and $\mathrm{CD} 8^{-} \mathrm{NK}$ cells were analyzed by flow cytometry for granzyme A or perforin expression. The histograms show data from at least $1,000 \mathrm{CD}^{+}$or $\mathrm{CD}^{-} \mathrm{NK}$ cells from one representative individual out of five analyzed; white areas indicate isotype controls. b NK-sensitive target cells (K562, 10,000 per well) were cultured alone or in presence of NK cell subsets for $2 \mathrm{~h}$. Live and killed target cells were then detected by flow cytometry by a combination of propidium iodide and anti-CD71 staining. The results show means $+\mathrm{SD}$ of duplicate wells from one individual. The experiment was repeated four times with similar results.

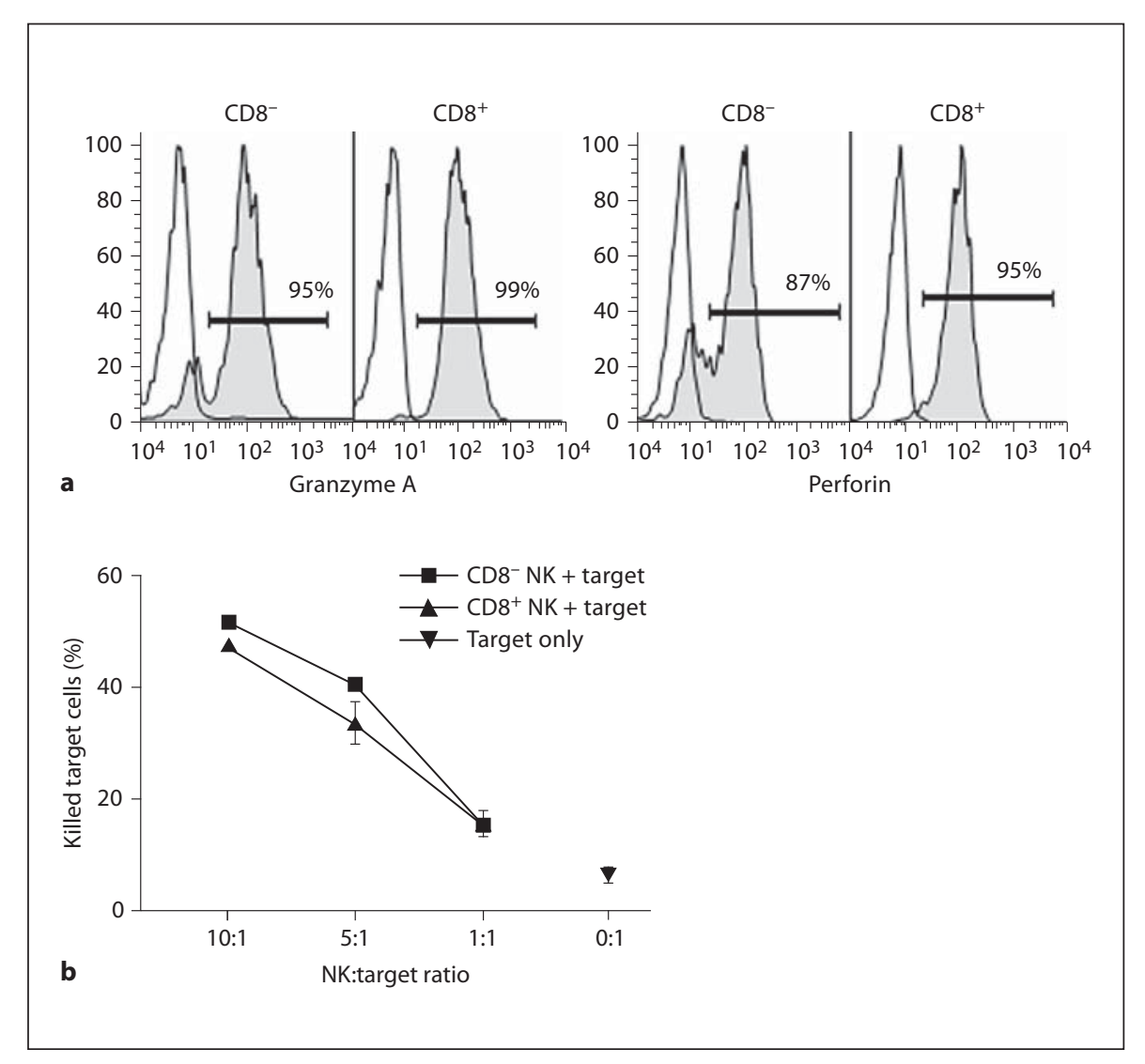

\section{Discussion}

The role of NK cells in bacterial infection is unclear; however, we and others have shown that peripheral NK cells are able to respond to bacteria with IFN- $\gamma$ production $[8,9]$. Since the most likely site of encounter between NK cells and bacteria is the gastrointestinal mucosa, it is of great interest to study the properties of NK cells at this location. Although the presence of both $\mathrm{CD}^{+}$and $\mathrm{CD}^{-} \mathrm{NK}$ cells in the blood has been described previously [14-16], this is to our knowledge the first report of a selective presence of either of the two populations in any peripheral tissue. The $\mathrm{CD} 8^{-} \mathrm{NK}$ cells in the mucosa seem to be a defined subset of NK cells which may be both CD56 ${ }^{\text {dim }}$ and CD56 ${ }^{\text {bright }}$. CD16-expressing NK cells in duodenal, colonic and decidual mucosa are predominantly $\mathrm{CD}^{-} 6^{-}$, while $>90 \%$ of the NK cells in peripheral blood are CD16 ${ }^{+}[12]$. This is in agreement with our results, which also show that most CD16 ${ }^{+}$ $\mathrm{NK}$ cells in the peripheral blood are $\mathrm{CD} 8^{+}$as well (fig. 1f). The higher levels of CD56 expression (CD56 ${ }^{\text {bright }}$ ) in mucosal NK cells compared to cells from peripheral blood ([9] and fig. 1a-c) suggest a primary role of cytokine production rather than cytotoxic function of many mucosal NK cells, since human NK cells have been suggested to be subdivided into largely cytokineproducing immunoregulatory (CD56 ${ }^{\text {bright }}$ ) and cytotoxic (CD56 $\left.{ }^{\mathrm{dim}}\right)$ subtypes $[4,7]$.

One possible reason for the selective increase in $\mathrm{CD} 8^{-}$ NK cells in mucosa could be that there is a higher survival of $\mathrm{CD}^{-} \mathrm{NK}$ cells in the gastrointestinal tissue. However, this is unlikely considering the fact that ligation of CD8 on NK cells inhibits NK cell apoptosis [17], which would rather lead to an accumulation of $\mathrm{CD}^{+} \mathrm{NK}$ cells in tissue over time. Alternatively, there may be a preferential migration of $\mathrm{CD}^{-} \mathrm{NK}$ cells into the mucosa, due to differential expression of chemokine receptors on the different NK cell subsets. This will be addressed in forthcoming studies.

The differences in characteristics between mucosal NK cells and NK cells from peripheral blood do not seem to have an effect on the ability to produce $H$. pylori-in- 
duced IFN- $\gamma . H$. pylori lysate stimulation of mucosal NK showed that NK cells from stomach mucosa produced IFN- $\gamma$ in response to a combination of IL-12 and $H$. $p y$ lori lysate (fig. 2a). Thus, we confirmed that NK cells purified from mucosal tissue were in fact responsive to bacterial stimulation. Furthermore, the presence of a CD56 $6^{\text {bright }}$ subpopulation among both $\mathrm{CD} 8^{+}$and $\mathrm{CD} 8^{-}$ NK cells suggests that both cell types have the capacity to respond with cytokine production. The two-fold higher frequency of CD56 ${ }^{\text {bright }}$ among the $\mathrm{CD} 8^{-} \mathrm{NK}$ cells (fig. 1e) is unlikely to be sufficient to account for the more than six-fold difference in $H$.-pylori-induced IFN- $\gamma$ production between these populations. This is also demonstrated by the fact that $\mathrm{CD} 8^{+}$and $\mathrm{CD} 8^{-} \mathrm{NK}$ cell populations are equally capable of producing IFN- $\gamma$ after stimulation with cytokines only, in the absence of bacterial products (fig. 3a-c). This indicates that although the CD56 ${ }^{\text {bright }}$ $\mathrm{CD} 16^{-} \mathrm{NK}$ cells are generally considered to be the cytokine-producing subset $[5,6]$, the $\mathrm{CD}^{+}$and hence $\mathrm{CD} 16^{+}$ CD56 $6^{\text {bright/dim }}$ subset is also fully capable of producing cytokines.

The mechanism responsible for the differential response to bacteria is currently being investigated in our laboratory. Preliminary experiments reveal no differences in TLR expression between $\mathrm{CD} 8^{+}$and $\mathrm{CD} 8^{-} \mathrm{NK}$ cells (data not shown). Since the difference in IFN- $\gamma$ production of the two NK cell populations is only apparent after stimulation with bacterial products but not with cytokines, other parts of the TLR signaling pathways will also be analyzed. The $\mathrm{CD} 8^{+}$and $\mathrm{CD} 8^{-} \mathrm{NK}$ cell populations did not differ in their cytotoxic ability to kill K562 target cells, although the majority of the $\mathrm{CD} 8^{+} \mathrm{NK}$ cells were $\mathrm{CD} 56^{\mathrm{dim}} \mathrm{CD} 16^{+}$, which implies a predominantly cytotoxic function of the cells. This apparently contradicts another recent study by Addison et al. [17], which shows that $\mathrm{CD} 8^{+} \mathrm{NK}$ cells have a higher cy totoxic activity than $\mathrm{CD}^{-}$ NK cells, mediated by prevention of activation-induced apoptosis by ligation of $\mathrm{CD} 8 \alpha$. However, in our experiments we used a shorter incubation time in the cytotoxicity assay, so in agreement with the study by Addison et al., our results show that both $\mathrm{CD} 8^{+}$and $\mathrm{CD} 8^{-} \mathrm{NK}$ cells have an initial cytotoxic capacity, while from our experimental setting we cannot draw any conclusions about longer-term effects.

Taken together, we propose that $\mathrm{CD}^{-} \mathrm{CD}^{-}$ CD56 ${ }^{\text {bright }} \mathrm{NK}$ cells constitute a subset of NK cells that are present in the gastrointestinal mucosa and are especially adapted to responding against bacterial infection by production of cytokines. To our knowledge a functional role for $\mathrm{CD} 8^{-} \mathrm{NK}$ cells has previously not been proposed. This study may therefore have important implications for the understanding of the function of NK cells in the response to mucosal bacterial infections.

\section{Acknowledgements}

This study was supported by grants from the Swedish Cancer Society, from LUA/ALF-Göteborg, from the Swedish Research Council and from the Knut and Alice Wallenberg Foundation through support to the Gothenburg University Vaccine Research Institute (GUVAX).

\section{References}

1 Colucci F, Caligiuri MA, Di Santo JP: What does it take to make a natural killer? Nat Rev Immunol 2003;3:413-425.

$\checkmark 2$ Biron CA, Nguyen KB, Pien GC, Cousens LP, Salazar-Mather TP: Natural killer cells in antiviral defense: function and regulation by innate cytokines. Annu Rev Immunol 1999; $17: 189-220$

-3 Moretta L, Mingari MC, Bottino C, Pende D, Biassoni R, Moretta A: Cellular and molecular basis of natural killer and natural killerlike activity. Immunol Lett 2003;88:89-93.

-4 Cooper MA, Fehniger TA, Caligiuri MA: The biology of human natural killer cell subsets. Trends Immunol 2001;22:633-640.

$\checkmark 5$ Caligiuri MA: Human natural killer cells. Blood 2008;112:461-469.
6 Cooper MA, Fehniger TA, Turner SC, Chen KS, Ghaheri BA, Ghayur T, Carson WE, Caligiuri MA: Human natural killer cells: a unique innate immunoregulatory role for the cd56 $6^{\text {bright }}$ subset. Blood 2001;97:31463151.

7 Farag SS, Caligiuri MA: Human natural killer cell development and biology. Blood Rev 2006;20:123-137.

8 Iho S, Yamamoto T, Takahashi T, Yamamoto S: Oligodeoxynucleotides containing palindrome sequences with internal $5^{\prime}$-CPG-3' act directly on human $\mathrm{NK}$ and activated $\mathrm{T}$ cells to induce IFN- $\gamma$ production in vitro. J Immunol 1999;163:3642-3652.
\$9 Yun $\mathrm{CH}$, Lundgren A, Azem J, Sjoling A Holmgren J, Svennerholm AM, Lundin BS: Natural killer cells and Helicobacter pylori infection: bacterial antigens and interleukin-12 act synergistically to induce $\gamma$ interferon production. Infect Immun 2005; 73 : 1482-1490.

10 Tarkkanen J, Kosunen TU, Saksela E: Contact of lymphocytes with Helicobacter pylori augments natural killer cell activity and induces production of $\gamma$ interferon. Infect Immun 1993;61:3012-3016.

-11 Pellicano A, Sebkova L, Monteleone G, Guarnieri G, Imeneo M, Pallone F, Luzza F: Interleukin-12 drives the TH1 signaling pathway in Helicobacter pylori-infected human gastric mucosa. Infect Immun 2007;75: 1738-1744. 
12 Moller MJ, Kammerer R, von Kleist S: A distinct distribution of natural killer cell subgroups in human tissues and blood. Int J Cancer 1998;78:533-538.

13 Pang G, Buret A, Batey RT, Chen QY, Couch L, Cripps A, Clancy R: Morphological, phenotypic and functional characteristics of a pure population of CD56+ CD16- CD3large granular lymphocytes generated from human duodenal mucosa. Immunology 1993;79:498-505.

14 Jonges LE, Albertsson P, van Vlierberghe RL, Ensink NG, Johansson BR, van de Velde CJ, Fleuren GJ, Nannmark U, Kuppen PJ: The phenotypic heterogeneity of human natural killer cells: presence of at least 48 different subsets in the peripheral blood. Scand J Immunol 2001;53:103-110.
15 Lanier LL, Le AM, Phillips JH, Warner NL, Babcock GF: Subpopulations of human natural killer cells defined by expression of the Leu-7 (HNK-1) and Leu-11 (NK-15) antigens. J Immunol 1983;131:1789-1796.

16 Lucia B, Jennings C, Cauda R, Ortona L, Landay AL: Evidence of a selective depletion of a CD16+ CD56+ CD8+ natural killer cell subset during HIV infection. Cytometry 1995; 22:10-15.

17 Addison EG, North J, Bakhsh I, Marden C, Haq S, Al-Sarraj S, Malayeri R, Wickremasinghe RG, Davies JK, Lowdell MW: Ligation of CD8 $\alpha$ on human natural killer cells prevents activation-induced apoptosis and enhances cytolytic activity. Immunology 2005 ; 116:354-361.

18 Raghavan S, Hjulstrom M, Holmgren J, Svennerholm AM: Protection against experimental Helicobacter pylori infection after immunization with inactivated $H$. pylori whole-cell vaccines. Infect Immun 2002;70: 6383-6388.
19 Mattsson A, Tinnert A, Hamlet A, Lonroth $\mathrm{H}$, Bolin I, Svennerholm AM: Specific antibodies in sera and gastric aspirates of symptomatic and asymptomatic Helicobacter pylori-infected subjects. Clin Diagn Lab Immunol 1998;5:288-293.

20 Lundgren A, Stromberg E, Sjoling A, Lindholm C, Enarsson K, Edebo A, Johnsson E, Suri-Payer E, Larsson P, Rudin A, Svennerholm AM, Lundin BS: Mucosal FOXP3-expressing $\mathrm{CD} 4+\mathrm{CD} 25$ high regulatory $\mathrm{T}$ cells in Helicobacter pylori-infected patients. Infect Immun 2005;73:523-531.

21 Lundin BS, Johansson C, Svennerholm AM: Oral immunization with a Salmonella enterica serovar typhi vaccine induces specific circulating mucosa-homing $\mathrm{CD} 4+$ and CD8+ $\mathrm{T}$ cells in humans. Infect Immun 2002;70:5622-5627. 